\title{
Gender specifics in entrepreneurs' personal characteristics
}

\author{
Karin Širec, Dijana Močnik ${ }^{* *}$
}

This paper explored Slovenian entrepreneurs' personal characteristics to understand the existing gender gap in transitional countries, testing the proposed model among small and medium-sized company owners $(N=201$; $32.3 \%$ female, $67.7 \%$ male). The research operationalized entrepreneurs' characteristics according to psychological and non-psychological motivation factors; the former resulted in four types of Slovenian entrepreneurs while the latter was divided into human and social capital. Significant differences emerged among genders related to certain psychological motivation factors and social capital categories, but not human capital. Women remain an unexploited source of entrepreneurship; thus, Slovenia should establish effective mechanisms to promote female entrepreneurship.

Der vorliegende Artikel untersucht die persönlichen Merkmale slowenischer Unternehmer/innen, um die vorhandene Geschlechterschere in Transformationsländern zu verstehen. Das vorgestellte Modell wurde anhand von Unternehmenseigentümer/innen kleiner und mittelständischer Unternehmen getestet $(N=201 ; 32,3 \%$ weiblich, 67,7\% männlich). Die Untersuchung operationalisierte Merkmale der Unternehmer/innen hinsichtlich psychologischer und nicht-psychologischer Motivationsfaktoren; erstere hatten vier slowenische Unternehmertypen zum Ergebnis, während letztere untergliedert wurden in Human- und Sozialkapital. Signifikante Unterschiede traten zwischen den Geschlechtern bezüglich bestimmter psychologischer Motivations- und Sozialkapitalfaktoren auf, nicht jedoch beim Humankapital. Frauen bleiben weiterhin eine ungenutzte Quelle des Unternehmertums; deshalb sollte Slowenien effektive Mechanismen zur Förderung weiblichen Unternehmertums etablieren.

Keywords: entrepreneurship, entrepreneurship theory, SME, entrepreneurs' personal characteristics, male and female entrepreneurs

* Manuscript received: 05.12.2009, accepted 10.11.2011 (2 revisions)

** Karin Širec, PhD, Assistant Professor, Faculty of Economics and Business, University of Maribor. Main research areas: Organisational behaviour, entrepreneurship, female entrepreneurship, SME growth. Corresponding address: karin.sirec@uni-mb.si

Dijana Močnik, PhD, Associate Professor, Faculty of Electrical Engineering and Computer Science, University of Maribor. Main research areas: Organisation and management, strategic management, organisational behaviour, transaction cost economics, industrial organization, entrepreneurial finance. 


\section{Introduction}

Since the publication of the Bolton Report in 1971, the contribution of entrepreneurs to economic growth, job creation, innovation, and promotion of enterprises has been widely recognized (Jones/Tilley 2003: 1). At the same time, entrepreneurs are rare. In the US, Sweden, and Germany, only one in ten employed individuals is self-employed (Caliendo et al. 2011). In 2010, the TEA index ${ }^{1}$ for Slovenia was 4.56, placing Slovenia in the lowest fifth among 59 GEM $^{2}$ countries (Rebernik et al. 2011). Becoming attached by either an entrepreneurial or employed occupational career is a matter of many factors, including biography (Müller 2001), age (Mondragon-Velez 2009), gender (Minniti/Nardone 2007), education (Van der Sluis et al. 2008), and personality (Müller/Gappisch 2005). Personality variables are a potential source for explaining the development of self-employed entrepreneurs as well as potential differences in entrepreneurial types between male and female entrepreneurs. The gender perspective is important because of the limited understanding of the gendered influences of economic development that entrepreneurship activity undoubtedly has on a society.

The current research concentrates on the personal characteristics of Slovenian entrepreneurs - an area that requires an interdisciplinary approach. The domains of psychology, sociology, and economics all seem to provide insight into a piece of the puzzle, but none seems to explain the phenomenon completely. Many decisions in small firms depend on so-called human factors-namely, the personal characteristics of the owner-entrepreneur. The recognition and exploitation of opportunities are neither self-evident phenomena nor matters of chance, but are a result of clear, positively motivated business intentions and actions on the part of the owner-entrepreneur, driven by the belief that he or she can produce the desired outcomes (Gray 2000; Maki/Pukkinen 2000).

The literature on entrepreneurship has uncovered differences in the rate of entrepreneurship between men and women, with women generally displaying less entrepreneurial activity than men. Prior research into personality variables included areas such as entrepreneurial career intentions (e.g., Zhao et al. 2005), entrepreneurial cognition and opportunity recognition (e.g., Ardichvili et al. 2003), entrepreneurial role motivation (e.g., Miner 1993), and new venture survival (e.g., Ciavarella et al. 2004). At least three studies have investigated entrepreneurial types (Miner 1997; Reynierse 1997; Müller/Gappisch 2005). However, many of these previous studies involved a confusing variety of personality variables, which is one of the main purposes for the current

1 TEA index: the index that identifies early-stage entrepreneurial activity in a certain country.

2 GEM was created in 1997. Focusing primarily on entrepreneurship, it studies determinants that impact national levels of entrepreneurial activity and economic growth. See www.gemconsortium.org. 
research-namely, developing a framework for the conceptualization of the discussed entrepreneurship phenomena that incorporate measures for the operationalization of entrepreneurs' personal characteristics regarding gender differences, which have not yet been examined in previous work. The current paper stemmed from the desire to explore personal characteristics of male and female Slovenian entrepreneurs as well as the perception that some differences may exist between them, which could help better understand and react to the existing gender gap in Slovenian entrepreneurship as well as in other transitional countries. The research concentrates on the operationalization of entrepreneurs' personal characteristics through division into psychological and nonpsychological motivation factors. Using psychological motivation factors, we define the personality types of male and female Slovenian entrepreneurs. Thus, the research involves investigating broader aspects of entrepreneurial phenomena and opening a vast space for further investigations.

The paper is structured as follows. First, we offer an introduction to the topic under study and the aim we wish to achieve. In the second section, we explain the theoretical framework and derived hypotheses. The subsequent two sections describe data, variables, and the research method. In section five, we gather the obtained results and discussion. Finally we illustrate the main conclusions obtained in the study and some policy implications.

\section{Literature review and hypothesis development}

\section{Gender specifics in the transitional context}

Entrepreneurship is a complex phenomenon involving the individual, firm, and environment within which it occurs (Begley 1995, as cited in Solymossy 1998: 5). However, the nature of the relationship among these three elements is not understood (Solymossy 1998: 5). The concept of entrepreneurial individuals with distinguishing characteristics is central to entrepreneurial theory. The current paper investigates the differences in personal characteristics, whichaccording to entrepreneurship theory - can be divided into psychological and non-psychological motivation factors. The proposed study derives from the social feminist theory (Fisher et al. 1993), which posits that men and women differ due to differences in the socialization processes they experience. Males and females are viewed as two separate groups, each with equally effective and valid - but distinct - ways of thinking and rationalizing (Johnsen/McMahon 2005). Social feminist theory expects findings on men and women to differ in terms of the motivation to start and run a business, business skills, level of education, measurements of success, level of self-confidence, personal attributes, and prioritization of business tasks (Moore/Buttner 1997).

Female entrepreneurs are a diverse and complex group, with varied backgrounds, circumstances, and worldviews. The majority of research has found that female entrepreneurs generally underperform male entrepreneurs on a 
variety of measures, including revenues, profit, growth, and discontinuance rates (Cooper et al. 1994; Rosa et al. 1996; Fasci/Valdez 1998; Du Rietz/Henrekson 2000). Moreover, an extensive literature review of studies on gender issues from the past 25 years demonstrated that many questions still remain unanswered (Greene et al. 2003), particularly in three primary areas: human capital, strategic choice, and structural barriers. In most countries, the share of men in the start-up phases of entrepreneurship is much higher than that of women, as described by GEM research. Empirical evidence can also be found in a recent GEM research report on women and entrepreneurship (Bosma/Levie 2010), which reveals a clear picture of the gender gap in venture creation and ownership activity. Earlystage female entrepreneurs in Slovenia account for only 24.2 per cent (Rebernik et al. 2010). In almost all participating GEM countries in 2009, the structure by gender reveals that men are more entrepreneurially active than women.

Furthermore, additional circumstances should be considered. Slovenia, as a Central and Eastern European country, is facing a transition process that is not yet complete, despite Slovenia's May 2004 entry into the European Union. Transitional countries share many common features with regard to female participation in the labour force, including the average level of education and gender wage gap. The transition process has affected both men and women, creating a loss in job security and employment costs; however, women seem to have taken over a larger share of the adjustment costs (Ruminska-Zimny 2003). Moreover, transition changes have also had important and often negative effects on women's position in society (Stoyanovska 2001), whereas under the communist regime, men and women were supposedly equal in all social aspects. According to Gal and Kligman (2000), state socialism only officially supported equality between men and women through women's full participation in the labour force. With the fall of the communist regime, structural inequalities between men and women became evident (Tominc 2002), as did the challenge inherent in learning the inner workings of the market economy (Ogloblin 1999).

\section{Research hypothesis introduction}

\section{Psychological motivation factors}

The concept of personality type refers to the psychological classification of different types of individuals. Although typologies of all sorts have existed throughout time, the most influential idea of psychological types originated in the theoretical work of Carl Jung, which has served as the root for all modern typologies.

Personality variables, traditionally studied by psychologists and incorporated only more recently by economists, are a potential source for explaining differences between genders. Based on a survey of the extended literature, Klapper and Parker (2010) concluded that external factors (e.g., business environment, access to finance, work-family conflicts) only partially explain the 
gender gap in entrepreneurship, which is why our paper focuses on the role of personal characteristics. The relationship between personality characteristics and entrepreneurship has been examined in a number of studies, and recent metaanalyses confirm a significant correlation between personality characteristics and entrepreneurial behaviour (e.g., Zhao/Seibert 2006; Zhao et al. 2010). However, the contribution of personality characteristics to the gender gap in entrepreneurship has been examined by only a few empirical studies (e.g., van der Zwan et al. 2011; Verheul et al. 2011).

Even if accepted that personality variables partially explain entrepreneurial processes, a debate remains over which set of personality variables is relevant. Zhao and Seibert (2006) advocate that, regarding general personality traits, the Big Five construct is a fundamental approach; for reasons of reliability and validity, it is better able to identify the relevant relationships between traits and entrepreneurial developments than more specific personality characteristics. However, others argue that this general traits approach is not sufficiently related to entrepreneurial tasks (Dudley et al. 2006). Furthermore, Barrick and Mount (2005: 367) point out that "narrow traits rely on explicit description of entrepreneurial activities that may be situated in time, place and role," which is why specific personality characteristics are more useful in predicting entrepreneurial performance than the Big Five approach.

Thus, conflicting evidence exists at different levels and hierarchies. First, at the fundamental level, some researchers suggest that personality is unimportant while others assign it a crucial role as differences in personality characteristics may explain why some individuals become successful entrepreneurs and others do not. Then, assuming that personality matters, a debate has ensued about whether it is best measured in terms of the Big Five construct or whether specific personality characteristics should be used in the context of entrepreneurship. Finally, a discussion has emerged regarding whether certain variables relevant for entrepreneurs should be separately examined or are reflected by a combined specific set of the general personality traits construct (Caliendo et al. 2011: 2).

This paper systematically analyzes gender differences in personality characteristics. It emphasizes that entrepreneurs need not only knowledge, expertise, and professional competencies, but also a variety of skills and abilities influenced by personality characteristics. In order to be able to estimate the true effects of personality on entrepreneurship, personality characteristics related to entrepreneurial tasks need to be identified. Typical examples of personality characteristics matching entrepreneurial tasks include need for achievement (see McClelland 1961), locus of control (Rotter 1966), risk tolerance (Kihlstrom/Laffont 1979), need for autonomy/independence (Brandstätter 1997), and self-esteem/self-efficacy (Korman 1970). 
Rauch and Frese (2007) described a list of specific personality characteristics related to the tasks of entrepreneurial activities. In our data set, personality characteristics - addressed as psychological motivation factors - were discussed in three separate groups: general entrepreneurial motivation, core selfevaluation, and entrepreneurs' cognitive characteristics. The first group (general entrepreneurial motivation) includes the need for achievement, risk taking, and the need for independence. The element of extraversion, which clearly belongs to general entrepreneurial motivation and derives from broad psychological theory (the Big Five), was excluded due to the need for extensive measurements as well as the previously stated arguments. In the second group (core selfevaluation), the model investigated self-esteem, self-efficacy, and locus of control. The third group refers to entrepreneurs' cognitive characteristics and comprises vision, overconfidence, and intuition; this group is not included in our model for the same previously stated arguments. The theoretical background and measurement instruments of the proposed personality characteristics are explained in section 4 .

Personality theorists agree that an individual's personality predicts his or her behaviour (Funder, 1994). For a better understanding of the gender gap and to design appropriate entrepreneurship policy measures, it is important to examine the contribution of personality characteristics through the testing of hypothesis 1. Based on the testing results, the aim of the current research is to identify the personality types of male and female Slovenian entrepreneurs.

Hypothesis 1: Psychological motivation factors differ between male and female Slovenian entrepreneurs.

\section{Non-psychological motivation factors}

\section{Human capital}

Human capital refers to the range of valuable skills and knowledge a person has accumulated over time (Burt 1992). The knowledge entrepreneurs accumulate has two complementary dimensions: tacit and explicit knowledge (Polanyi 1967; Rebernik/Širec 2007). Tacit knowledge refers to "know-how", the often noncodified components of activity. The acquisition of human capital improves the conditions for an individual to act in new ways (Coleman 1988) and represents the core capability of an entrepreneur. When profitable opportunities for new economic activities exist, individuals with a higher level of human capital should more effectively identify and develop them.

In this context, the OECD Report (2004) on female entrepreneurship highlighted a fundamental feature of the market that is significant for the research presented in this chapter - namely, the portioning of knowledge among individuals. Such knowledge is idiosyncratic because it is acquired through each individual's personal experiences and from areas such as individual occupations, on-the-job routines, social relationships, and daily life (Acs 2002). Women differ from men 
in their experience because they hold different occupations (often less appropriate for self-employment and entrepreneurship). Statistical data for the second quarter of 2008 (Statistical Office of the Republic of Slovenia, 2009) indicate that women represented 50.7 per cent of active paid employment in Slovenia. The highest percentage of active working women occurred in service and sales workers (65 per cent), clerks (64 per cent), and professionals (60.7 per cent). The lowest occupation groups were in non-industrial types of work ( 8 per cent), which is why they have different on-the-job routines, social relationships, and daily life activities. Moreover, women identify business opportunities differently and try to exploit them differently. On the other hand, Slovenian women are generally a little more educated than men, especially among $25-$ to 44-year-olds, which includes twice as many women with higher post-graduate education than men (16.6 per cent of women versus 8.6 per cent of men). Yet women earn on average only 93 per cent of the average man's gross monthly salary. Accordingly:

Hypothesis 2: Human capital, repredented by tacit and explicit knowledge and skills, differs between male and female Slovenian entrepreneurs.

\section{Social capital}

Social capital is viewed as a key facilitator of resource exchanges (particularly knowledge) within and between firms; therefore, it can be an important catalyst of value creation (Aldrich 1999; Maula et al. 2001). A social capital approach suggests that non-economic knowledge emerges from norms, networks, and social relationships - all of which have the potential to become important resources for new ventures (Coleman 1988; Nahapiet/Ghoshal 1998).

For the purpose of our study, we defined social capital as a structure of relations among individuals, society, and social networks. Our research focuses on three dimensions of individual social capital: structural, relational and cognitive, as defined by Ghoshal and Nahaphiet (1998). The structural dimension refers to the impersonal pattern of ties among people - namely, the "hardware" of social networks. The relational dimension represents the quality of individuals' personal relations (Granovetter 1992) that influence people's behaviour and meet their social motives (e.g., respect, friendship, trust, reliability). Cognitive capital reflects the degree to which the individual participates in a common value system within an existing company. These resources provide the common ideas, interpretations, and systems of meanings.

As previously stated, a common characteristic of labour market developments during the transition process is gender asymmetry, as seen in employment, sectoral changes of employment, income and wages, access to jobs in the private sector, etc. Smallbone and Welter (2001) pointed out that the distinctive features of entrepreneurial behaviour reflect the unstable and hostile nature of the external environment as well as the scarcity of various key resources. In such 
circumstances, informal networks often play a key role in helping entrepreneurs mobilise resources, win orders, and cope with the constraints at different levels of the economic system as well as society as a whole. These findings concur with the research results related to female entrepreneurship in Slovenia (Drnovšek/Glas 2006), which indicated that women entrepreneurs lack networking components and social capital assets as they have to contract these resources through their strong ties with family members.

Evidence suggests that women are less involved in networks than men and that their types of networks differ. The strong personal networks in which women traditionally engage are those linked mainly to family-related tasks (Lin 1999). In transitional countries, such gender differences appear to be even more pronounced (Smallbone/Welter 2001; Drnovšek/Glas, 2006). Accordingly:

\section{Hypothesis 3: Social capital differs between male and female Slovenian entrepreneurs.}

First, a framework for the conceptualization of entrepreneurship incorporating measures relating to the personal characteristics was developed by refining previously proposed, but inadequately tested, theoretical constructs in an empirically testable framework. The second, and closely related, objective of this research is to develop and test a valid and reliable survey instrument that lends itself to establishing this framework for future research. Furthermore, the paper will separately test personal characteristics for male and female entrepreneurs, thereby making a unique contribution to female entrepreneurship investigations. 
Figure 1: The frame of the analysis (Širec 2007)

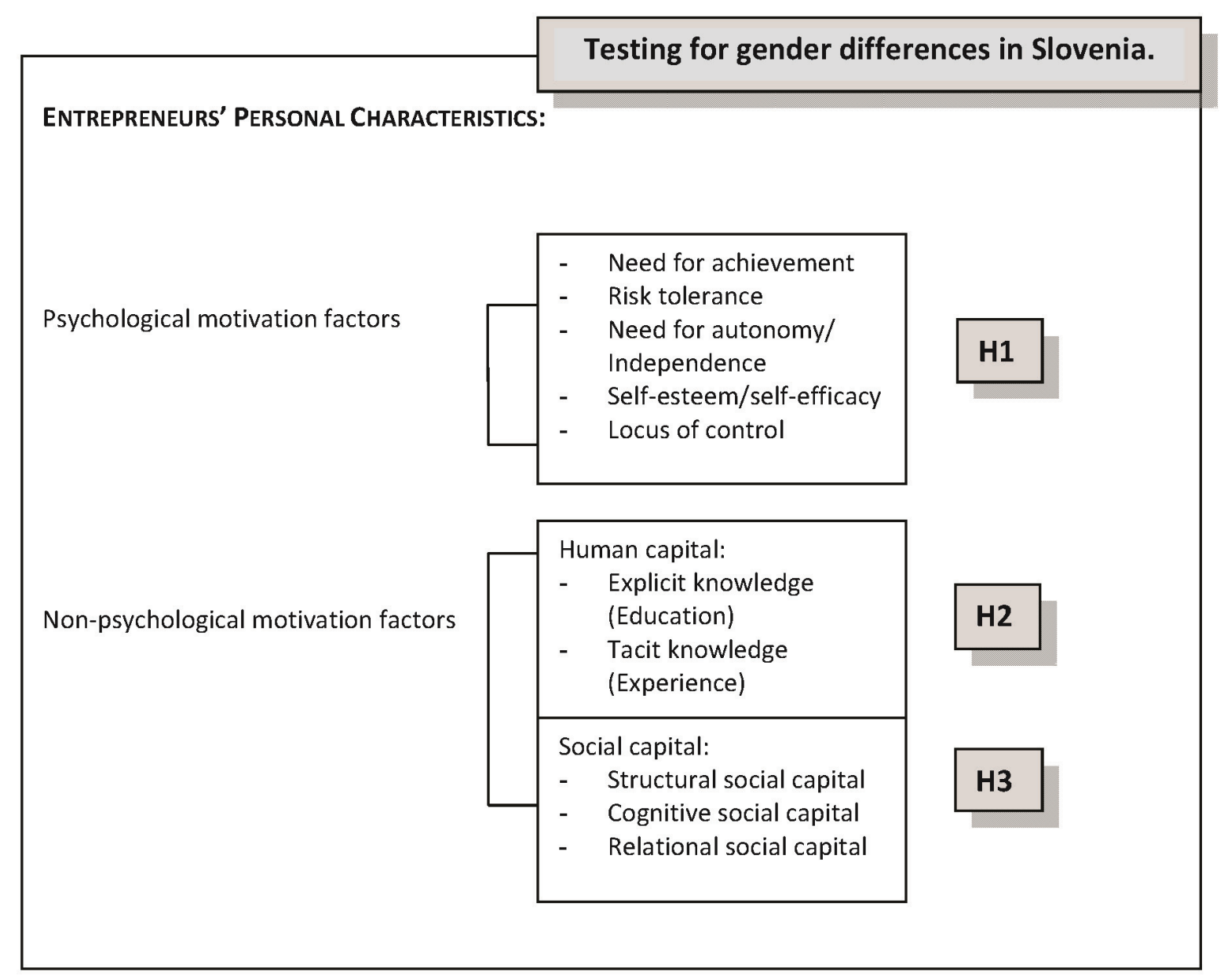

\section{Data}

The statistical population of the current research are entrepreneurs in Slovenian small and medium-sized companies (joint-stock companies, limited liability companies, non-limited liability companies) in all Standard Industry Classification (SIC) categories. In our sample we have identified them with the introductory question: "Do you own or co-own the company, that you are also helping to manage?". The sample $(\mathrm{N}=201)$ included $32.3 \%$ female and $67.7 \%$ male respondents, which correspond with the share of male and female entrepreneurs in Slovenian population (70:30). The research used quota sampling, as one aspect of non-probability sampling. Obvious advantages of quota sampling are the speed with which information can be collected, the lower cost of doing so, and its convenience. In quota sampling, the population is first segmented into mutually exclusive sub-groups, just as in stratified sampling. Judgment is subsequently used to select the subjects or units from each segment, based on a specified proportion (in the current case, company size, regional representation, SIC representation, and appropriate share of males and females in the sample). Yet these samples may be biased because not everyone gets a chance for selection. This random element underscores the greatest weakness of 
this approach. Indeed, quota versus probability has been a matter of controversy for many years.

Questionnaires were used to gather data concerning company owners. A central difficulty with research trying to accumulate primary data about companies' activities - particularly in the current case-is the specialty of the information desired, which interferes with the very personal domain of psychological motivation factors, as well as how to ensure a satisfactory response rate. The preparation and realization of research have been subordinated to the need to ensure the highest possible response rate. In the current study, interviews were conducted using the Computer Assisted Telephone Interviewing (CATI) method, resulting in a response rate of $11.4 \%$. Questions were prepared according to the interviewing method and the desired response rate. No openended questions were used to help ensure simplicity for those completing the questionnaire.

\section{Variables and methods}

This section describes the measurements for all investigated categories, as drawn from existing research literature. The discussion will further review the testing, which culminated in the selection of measures for examining the elements of individual personal characteristics.

\section{Psychological motivation factors}

This section will present descriptions of measurement instruments related to entrepreneurial personality characteristics according to the previously proposed dimensions. For each category we are presenting questions being addressed to respondents. For the purpose of this research, a 5-point scale was used, where 1 signifies that the respondent completely disagrees with the statement; 2 signifies the respondent partially disagrees with the statement; 3 signifies the respondent neither agrees nor disagrees with the statement; 4 signifies the respondent pretty much agrees with the statement; and, finally, 5 signifies the respondent completely agrees with the statement.

\section{Need for achievement}

The need to achieve is based on the motive to do well and achieve a goal according to a set of standards. The inclusion of measures of achievement orientation within the framework of entrepreneurs' personal characteristics is consistent with previous research (e.g., Shanthakumar 1992; Johnson 1994; Solymossy 1998). Early research found that the need to achieve was the principal determinant of entrepreneurial behavioural orientation. Subsequent research demonstrated that it is related to independence orientation (Cooper 1986), risk-taking propensities (Sexton/Bowman 1986), and perception of control (Miller/Friesen 1982). 
The need to achieve reflects individuals' orientation, willingness, and drive for satisfaction or a sense of accomplishment as demonstrated by the exertion of intense, prolonged, and repeated efforts to accomplish something difficultwhether by skill, practice, or perseverance. This is accomplished by a futureoriented dedication to the task, involving the prioritization of accomplishing the task and frequently sacrificing other activities and personal time. The current research measured the need for achievement using the following questions formulated by Shanthakumar (1992) and Solymossy (1998):

- I push myself, and feel real satisfaction when my work is among the best there is.

- I judge my work by considering whether it meets the minimum requirements for the task.

- I am driven to ever-greater efforts by an unquenched ambition.

- I seldom get a sense of pride and accomplishment from my work.

- I spend more time thinking about my goals than my past accomplishments.

- My goals and ambitions are modest and easily achieved.

- Nothing that life can offer is a substitute for great achievement.

\section{Risk tolerance}

Despite the popular "myth" that entrepreneurs are high risk takers (Shaver 1995), research has consistently shown that entrepreneurs are moderate risk takers (e.g., Birley/Norburn 1987; Duchesneau/Gartner 1990; Shaver 1995). Kets de Vries (1977) further demonstrated that risk tolerance is related to the individual's self-confidence and his or her perceptions of control. Rotter's (1966) locus of control theory maintains that those with an internal locus of control might be perceived as high risk takers by others; however, because of their (entrepreneurial) perception of maintaining control in a given situation, they do not consider their risk as great as others might. The inclusion of measures for risk taking is thus consistent with entrepreneurship theory.

Risk taking presents individuals' disposition toward how much they will subject themselves to potential personal or financial loss or damage when confronted with uncertain circumstances or conditions. The current research measured the degree of risk taking again using questions formulated by Shanthakumar (1992) and Solymossy (1998):

- I am willing to risk my personal and family's material well-being for the sake of business.

- I buy insurance every time I travel. 
- I enjoy the uncertainty and risks of business since they energize me more than circumstances where there are predictable outcomes.

- I need to know that it's already been done before I'm willing to try it.

- I need to know the answer before I'll ask a question.

\section{Need for autonomy/independence}

Numerous profiles of successful entrepreneurs portray self-determined, independent pioneers who expressed their creativity and explored their ideas without the approval of others, refusing to accept the status quo. Such autonomy, or independent behaviour, is central to the entrepreneurship concept (Kets de Vreis 1977) and critical to the venture initiation process associated with entrepreneurship (Lumpkin and Dess 1996). Measures for autonomous behaviour are beginning to be pursued within the entrepreneurship field (e.g., Davidsson 1997; Autio et al. 1997). An orientation toward independent behaviour requires the ability and the will to be self-directed in the pursuit of opportunities (Autio et al. 1997), making it related to opportunistic behaviour, risk orientation, and innovative behaviour.

The need for autonomy reflects a tendency toward being free of the influence, authority, and control of others-whether in relation to authoritative organizational structures, personal dependency, or procedural constraints. The presence of autonomy is generally accompanied by an individual's willingness to accept the attendant risks and responsibilities resulting from one's actions. The current study measured such willingness using questions formulated by Shanthakumar (1992) and Solymossy (1998):

- I am quite independent of the opinions of others.

- I am uncomfortable when I have complete responsibility for deciding how and when to do my work.

- I find that I can think better when I have guidance and advice from others.

- I like a job in which I don't have to answer to anyone.

- I respect rules and established procedures because they guide me.

\section{Self-esteem and self-efficacy}

Within task-specific situations, self-esteem has been argued to be more influential upon entrepreneurial behaviour than the need for achievement (Arkes/Garske 1982). Self-esteem has further been found to be task-specific and socially influenced (Korman 1970). Self-esteem and self-efficacy reveal individuals' disposition in regard to how much they will subject themselves to potential personal or financial loss or damage when confronted with uncertain circumstances or conditions. 
The current study measured self-esteem and self-efficacy using questions formulated by Shanthakumar (1992) and Solymossy (1998):

- Because I'm unsure of myself, I spend a lot of time looking for someone who can tell me how to solve all my business problems.

- I am confident of my abilities and feel good about myself.

- I feel self-conscious when I am with very successful business people.

- I frequently have doubts about myself or my abilities when making business proposals.

- I worry about what my business associates think of me.

- My "knack for dealing with people" has enabled me to create many of my business opportunities.

\section{Locus of control}

Rotter's (1966) theories of control emphasize an individual's perceptions of the outcomes of events as being either within or beyond his or her control and understanding. Subsequent work suggested that the perception of control is task specific (Boyd/Vozikis 1994). Previous research further demonstrated that locus of control-together with other attitudes-differentiates entrepreneurs from non-entrepreneurs (Shanthakumar 1992).

Locus of control shows a person's tendency to believe that the outcome of events is within his or her ability to influence others, resulting in the acceptance of personal responsibility for the outcomes of his or her abilities and expertise rather than attributing the cause of events to serendipity, luck, or chance. This study measured locus of control using questions formulated by Solymossy (1998):

- I am in total control of my destiny.

- I am ultimately responsible for my own business success.

- I can control most situations in which I find myself.

- I frequently find myself in situations in which I am powerless to control the outcome.

- Most business circumstances happen because of luck, whether good or bad.

- What happens in my business is affected more by my abilities, control, and guidance than by external influences. 


\section{Non-psychological motivation factors}

\section{Human capital}

Measures for human capital are presented in two categories: explicit and tacit knowledge. The most common measure for general assessment of human capital is formal education completed (Becker 1993). Previous researchers (e.g., Honig 1998; Manolova et al. 2002) have measured this assessment in five categories. The current research added a sixth category: primary school. Thus, human capital was measured using the following categories: primary school; vocational and secondary school; high school; university degree; specialization, MBA, and master's degree; and doctor's degree. In addition, a question was included regarding whether or not the respondent is still in the process of acquiring formal education and whether or not he or she is accumulating expert knowledge through other means, such as conferences, workshops and seminars, and foreign language courses.

The current study measured tacit knowledge through years of work experience, possible previous managerial experience, and previous company ownership. Based on Ruzzier's (2004) research, the current study also included in the tacit knowledge investigation questions in which respondents evaluated their specific skills according to a 5-point scale. The study further incorporated a question about how a respondent estimates his or her own knowledge, skills, and abilities in the company's start-up phase from the GEM expert questionnaire.

\section{Social capital}

To measure components of social capital, the current study relied on the examples of Liao and Welsch (2003), who measured these components using dimensions defined by Nahapiet and Ghoshal (1998), in which social capital was divided into three groups: structural, cognitive, and relational social capital. Structural social capital has been investigated through the entrepreneur's personal network (network of relatives, friends, mentors, etc.). To measure cognitive social capital, the current study combined expert questions from GEM research with research by Liao and Welsch (2003) into four statements:

- In Slovenia, most people consider becoming an entrepreneur as a desirable career choice.

- In Slovenia, successful entrepreneurs have a high level of status and respect.

- In Slovenia, stories in the public media about successful entrepreneurs are common.

- Slovenian entrepreneurs are competent and resourceful individuals.

- Similarly, the research defined four statements for measuring relational social capital: 
- In Slovenia, we encourage young people to be independent and create new companies.

- In Slovenia, the state and local governments ensure good support for those who create new companies.

- In Slovenia, banks and other investors are benevolent to individuals who create new companies.

- In Slovenia, individual social groups (e.g. family, neighbourhood, religious communities) support individuals who create new companies.

- For the assessment of statements, a 5-point scale as described earlier was used again.

\section{Methodology}

The methodology for the current study relied on quantitative business research methods. After conducting an extensive literature and empirical research review to depict the current stage of knowledge regarding the determinants of entrepreneurs' personal characteristics, the Pearson correlation for data was used to measure the associations or correlation among variables. The Pearson correlation was used in the form of measurements of quantitative variables and the chi-square statistic $\chi^{2}$ for nominal data, together with phi coefficient $\Phi$ and Cramer's V. An independent sample t-test was used for quantitative variables to compare averages among various groups. The general criterion for accepting a hypothesis was that the difference was statistically significant at the 5 percent level (two-tailed test). A factor analysis was utilized for data reduction. The results (confirmation or rejection of the hypotheses) and comments - as well as suggestions for further research - will be discussed in the following section.

\section{Findings}

A condensed overview of the most important empirical research findings are discussed herein. Entrepreneurs' personal characteristics were operationalized according to theory based on psychological and non-psychological motivation factors. The analysis closely examined these characteristics and focused on gender peculiarities that showed statistically significant differences.

\section{Psychological motivation factors}

Psychological motivation factors were investigated with the help of the previously presented questions in the following domains: need for achievement, risk tolerance, need for autonomy/independence, self-esteem and self-efficacy, locus of control, and entrepreneurs' vision. The results indicate that Slovenian female entrepreneurs have a higher need for achievement than their male counterparts $\left(\mathrm{t}_{(192)}=-2.377, \mathrm{p}=0.018\right)$, whereas males are willing to tolerate higher risk than females $\left(\mathrm{t}_{(187)}=3.217, \mathrm{p}=0.002\right)$. The need for 
autonomy/independence is more explicit among males. The results indicated that women are a somewhat more prepared to respect rules and established working procedures than men and also feel more uncomfortable when they need to shoulder responsibility for deciding how and when to do their work. The need for autonomy factor resulted in no substantial gender-specific differences. Because of the presupposed connection between need for autonomy and company ownership, the study tested the empirical evidence of this linkage and confirmed that, in Slovenia, entrepreneurs who are sole owners express a higher need for autonomy than co-owners. Female respondents, on average, express slightly better results in the segment of investigating self-esteem and selfefficacy compared to men, yet opposite results are evident for locus of control. Women are, on average, more convinced that they control their own destinies and that what happens in business is more affected by their abilities, control, and guidance than external influences. Women also more often find themselves in situations in which they feel powerless to control the outcome $\left(\mathrm{t}_{(197)}=2.139, \mathrm{p}=\right.$ 0.034).

Second order EFA was used to test whether different types of entrepreneurs could be defined according to the gathered data in the different dimensions of psychological motivation factors. Data from previous studies show, that original test provides reliable and valid measures (Shanthakumar 1992; Solymossy 1998). Coefficients of internal consistency $(\alpha)$ were between 0.43 and 0.77 . In our case they lie in a range of 0.60 and 0.70 . After performing five factor analysis in domains of: need for achievement, risk tolerance, need for autonomy/independence, self-esteem and self-efficacy as well as locus of control we have identified 12 factors which have been used as inputs in the second order EFA that helped us define typology of Slovenian entrepreneurs. Four types of Slovenian entrepreneurs (for the whole sample - not gender specific) were identified: 
Table 1: EFA regarding types of Slovenian entrepreneurs

\begin{tabular}{|c|c|c|c|c|}
\hline $\begin{array}{c}\text { First-step } \\
\text { factor analysis } \\
\text { factors }\end{array}$ & Communalities & $\begin{array}{l}\text { Rotated } \\
\text { factors }\end{array}$ & $\begin{array}{c}\text { Defined factors- } \\
\text { types of } \\
\text { Slovenian } \\
\text { entrepreneurs }\end{array}$ & $\begin{array}{c}\text { Reliability } \\
\text { tests }\end{array}$ \\
\hline $\begin{array}{c}\mathrm{X}_{1} \\
\text { Future-oriented } \\
\text { entrepreneurs }\end{array}$ & 0.705 & 0.542 & \multirow{4}{*}{$\begin{array}{c}\text { TYPE } 1 \\
\text { Future-oriented, } \\
\text { cautious } \\
\text { entrepreneurs } \\
\text { with a low level } \\
\text { of self- } \\
\text { confidence and } \\
\text { self-esteem and } \\
\text { who like to } \\
\text { follow rules }\end{array}$} & \multirow{9}{*}{$\begin{array}{c}\text { Kaiser- } \\
\text { Meyer-Olkin: } \\
0.62 \\
\\
\text { Bartlett's Test } \\
\text { of Sphericity: } \\
\chi_{(66)}= \\
293.605, \\
p=0.000\end{array}$} \\
\hline $\begin{array}{c}\mathrm{X}_{2} \\
\text { Cautious } \\
\text { entrepreneurs }\end{array}$ & 0.643 & -0.761 & & \\
\hline $\begin{array}{c}\mathrm{X}_{3} \\
\text { Entrepreneurs } \\
\text { who like to } \\
\text { follow rules }\end{array}$ & 0.575 & 0.738 & & \\
\hline $\begin{array}{c}\mathrm{X}_{4} \\
\text { Entrepreneurs } \\
\text { concerned with } \\
\text { low levels of } \\
\text { self-confidence }\end{array}$ & 0.477 & 0.580 & & \\
\hline & & & & \\
\hline $\begin{array}{c}\mathrm{X}_{5} \\
\text { Highly } \\
\text { motivated } \\
\text { entrepreneurs }\end{array}$ & 0.514 & 0.664 & \multirow{4}{*}{$\begin{array}{c}\text { TYPE } 2 \\
\text { Highly } \\
\text { motivated, self- } \\
\text { confident, } \\
\text { independent } \\
\text { entrepreneurs } \\
\text { with an internal } \\
\text { locus of control }\end{array}$} & \\
\hline $\begin{array}{c}\mathrm{X}_{6} \\
\text { Independent } \\
\text { entrepreneurs }\end{array}$ & 0.353 & 0.492 & & \\
\hline $\begin{array}{c}\mathrm{X}_{7} \\
\text { Self-confident } \\
\text { entrepreneurs }\end{array}$ & 0.602 & 0.723 & & \\
\hline $\begin{array}{c}\mathrm{X}_{8} \\
\text { Entrepreneurs } \\
\text { with an } \\
\text { internal locus } \\
\text { of control }\end{array}$ & 0.487 & 0.696 & & \\
\hline
\end{tabular}




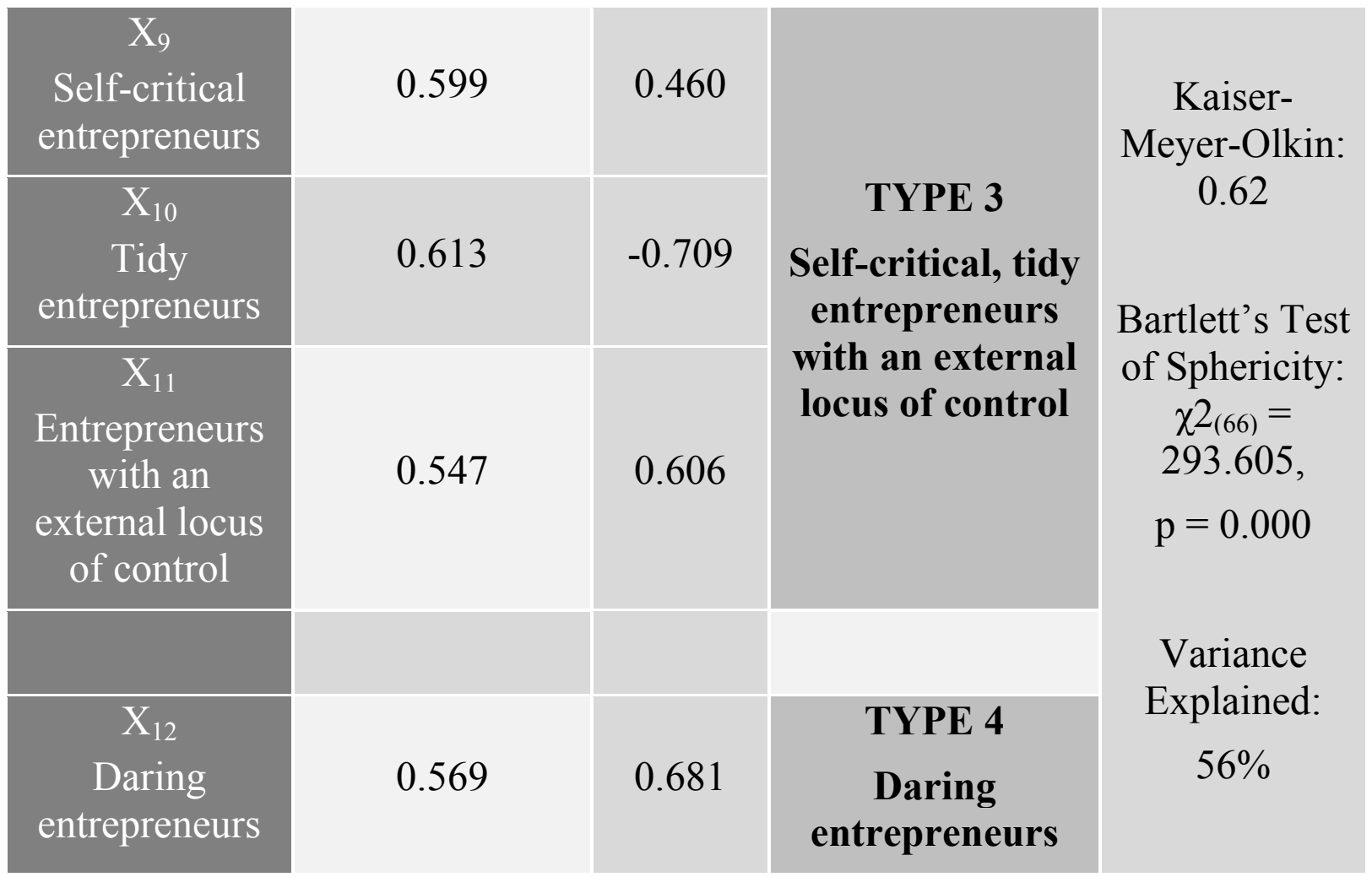

The defined types suggest that not all entrepreneurial types should be treated in the same way. Such an implication should be considered when establishing effective mechanisms for the promotion of entrepreneurship. Different types of entrepreneurs should be targeted in different ways. Another important implication is evident for institutional environment, such as financing institutions when deciding to support individual entrepreneurial projects (daring entrepreneurs should be treated differently than for example future-oriented, cautious entrepreneurs, etc.). This kind of conceptualisation should be considered in many other fields as well.

To identify gender-specific differences, the sample was split into male and female groups for a second-step factor analysis ${ }^{3}$, which resulted in the following four types of entrepreneurs for both genders:

\footnotetext{
${ }^{3}$ The detailed results of EFA could be provided by the author.
} 
Table 2: Gender-based types of entrepreneurs

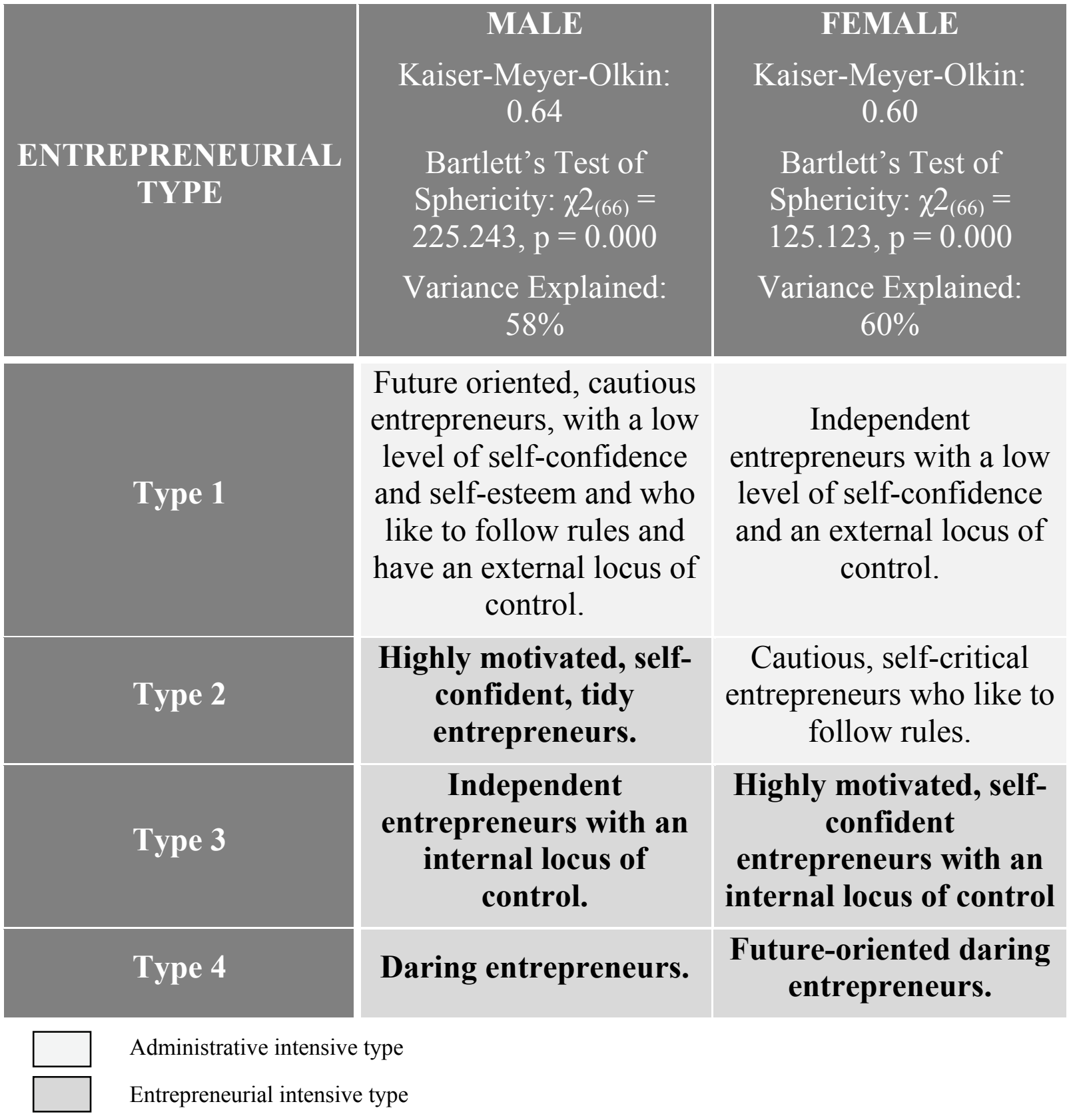

Thus, the gender-based definition of entrepreneurial types provides a much clearer picture that is in relative accordance with previously tested personality characteristics of both genders. As with Stevenson (1983) (signed in bold), three entrepreneurially intensive male types and two entrepreneurially intensive female types of Slovenian entrepreneurs were defined, which underscores the latest GEM (Global Entrepreneurship Monitor 2009) findings for Slovenianamely, that females express 2.2 times less entrepreneurial activity than men. At least a part of this gap may be explained by the described differences in entrepreneurs' personal characteristics.

The findings discussed herein confirm the first hypothesis. Some statistically significant gender differences have been established according to the researched 
components of psychological motivation factors as well as among the four defined types of entrepreneurs.

\section{Non-psychological motivation factors}

Non-psychological motivation factors were divided into so-called human and social capital.

\section{Human capital}

Within human capital research, this study analyzed respondents' explicit knowledge and tacit knowledge through previous experience.

- Explicit knowledge

- A high proportion of Slovenian entrepreneurs in our sample (40.8\%) have completed vocational and secondary education, while $37.8 \%$ have completed higher education. Only $18.9 \%$ have university degrees, while $2.5 \%$ have an area of specialization, an MBA, or a doctor's degree. Gender comparison shows a very similar relation. Among the respondents, no females had the highest degree of education (specialization, MBA, or a doctor's degree). However, it should be emphasized that a substantially higher rate of female respondents has a university degree $-24.6 \%$, compared to only $16.2 \%$ for men. Among vocational, secondary, and higher education, no statistically significant gender differences exist. The $\chi^{2}$ test did not confirm a statistically significant connection between gender and education level achieved: $\chi^{2}(2)=0.631, p>0.05$. Education is clearly a life-learning process that also occurs at a non-formal level in the workplace or elsewhere. Slovenian entrepreneurs are quite active in it; $14.4 \%$ of respondents are still in the process of acquiring a formal education, indicating a similar proportion of male and female respondents.

- Tacit knowledge

- Regarding years of work experience, no statistically significant differences exist between male and female respondents $\left(\chi^{2}(5)=6.783\right.$, $\mathrm{p}>0.05)$. In fact, $42.3 \%$ of respondents had no previous managerial experience (47.1\% male and $32.3 \%$ female) while $23.4 \%$ had been previous owners. More males $(25 \%)$ were in this category than females (20\%). respondents indicated that Slovenian entrepreneurs do have a good opinion about their abilities and that they have confidence in their own knowledge. Female respondents, on average, graded lower than men in the domain of analyzing and problem solving as well as in calculating skills. Interestingly, the domain of negotiation scored almost the same result for both genders. 
The results of the human capital categories investigated do not support the second hypothesis. Without regard to gender, the human capital categories studied show comparative accordance among themselves.

\section{Social capital}

Finally, structural, cognitive, and relational social capital analyses provided additional support. Structural social capital was measured using an assessment of respondents' personal networks. Individuals whose marital partners $\left(\chi^{2}(1)=\right.$ $7.059, p=0.008, \Phi=$ Cramer's $\mathrm{V}=0.187)$ or parents $\left(\chi^{2}(1)=7.480, \mathrm{p}=0.006\right.$, $\Phi=$ Cramer's $V=0.193)$ are entrepreneurs more often choose an entrepreneurial career. Female entrepreneurs estimated cognitive social capital in the sense of a positive relationship against entrepreneurship better than their male counterparts $\left(\mathrm{t}_{(170)}=-2.525, \mathrm{p}=0.012\right)$. It must be emphasized that Slovenian entrepreneurs assess relational social capital substantially lower than cognitive social capitalespecially among women $\left(\mathrm{t}_{(170)}=3.315, \mathrm{p}=0.001\right)$. Women miss out on state and local government support more often than men do.

A comparison to the findings of Liao and Welsch (2003) indicated that, in Slovenia, the average grade of cognitive and relational social capital components is lower than in the United States. The biggest gap between respondents' grades occurred in the grading of government start-up support as well as support from local authorities. Slovenian respondents graded them substantially lower than those in the United States. To summarize, Slovenian social capital was graded lower than social capital in the United States according to Liao and Welsch (2003).

Thus, the statistically significant differences in perception of studied social capital categories between genders confirmed hypothesis three.

\section{Conclusions and policy implications}

Female entrepreneurs should not be treated as a monolithic category as they are a complex group with diverse backgrounds, circumstances, and worldviews (Green/Cohen 1995). The European Forum of Female Entrepreneurship (European Commission 2003) identified the need to encourage member states to conduct research leading to reliable statistics in the field of female entrepreneurship. The current paper, although limited to a Slovenian sample, investigates gender differences in personal characteristics between male and female entrepreneurs. As such, the findings of the current research are particularly significant as differences between male and female owners could provide explanations for the existing gender gap in transitional economies' entrepreneurship.

Two recent research studies in entrepreneurship (the Slovenian Entrepreneurship Observatory 2009/10 and the Global Entrepreneurship Monitor 2010) indicated that entrepreneurial potential in Slovenia is not fully utilized due to resource 
scarcity, environmental uncertainty, and weak institutional endorsementsimilar issues facing other transitional environments. Indeed, a detailed examination of female entrepreneurship in Slovenia showed considerable unexploited possibilities deriving from the existing gender gap. It should be emphasized that female entrepreneurs in Slovenia do not usually face prejudice against their entrepreneurial career, and no legal obstacles limit women from owning an enterprise. Recently, appropriate legislation was adopted that grants equal opportunities to both genders (the Equal Opportunities Act, the Employment Act, and the Parental Protection and Family Benefits Act). Despite these conditions, women decide to become entrepreneurially active less frequently than men (Tominc/Rebernik, 2006).

Part of the explanation for this seeming contradiction can be found in proposed research that focuses on individuals' resources. In testing the proposed hypotheses herein, significant differences were identified among genders related to psychological motivation factors for entrepreneurship. However, the examination of human capital failed to show significant differences, although statistically significant differences in the perception of studied social capital categories between genders could be confirmed. When examining results more closely, some connections among studied components could be identified. Regarding personality characteristics, we identified significant differences between genders: Three entrepreneurially intensive male types and two entrepreneurially intensive female types of Slovenian entrepreneurs were defined. Most explicit differences on the side of female entrepreneurs resulted in their higher need for achievement and lower risk tolerance. As it is expected that a positive correlation exists between risk attitudes and the decision to become an entrepreneur, part of the gender gap is explained. Female entrepreneurs' ability to overcome the odds of taking appropriate risks could be improved through formal education and work experience (human capital) as well as access to networks (social capital), as informal and formal networks are of great importance. Stronger social ties provide access to valuable information needed in entrepreneurial endeavours. Networks can bring more abundant and more accurate information as well as increased cooperation and trust (Manev et al. 2005). Some researchers posit that, in transitional economies, informal networks often play a key role in helping entrepreneurs mobilize resources, win orders, and cope with the constraints imposed by highly bureaucratic structures and often openly hostile officials (Smallbone/Welter 2001; Duh/Štrukelj 2011). Social capital is an important initial resource endowment. Women should seek to foster their connections with potential partners, suppliers, and customers. The government should therefore strengthen the networks and cooperation as well as organize meetings and forums in which entrepreneurs can share their ideas and create informal links between each other.

Indeed, a supportive environment is essential as it should encourage men and women to decide to pursue an entrepreneurial career in the near future. This goal 
can be achieved through intensive supportive programs that provide the necessary information for entrepreneurs, ensure appropriate advice, and offer education and training. Different state institutions can promote such supportive programs.

The establishment of an adequate supportive environment provides an opportunity for the successful operation and growth of micro and small and medium-sized enterprises, encourages economic activity, and consequently increases the proportion of enterprises and entrepreneurs who- because of more favourable conditions and support from the environment-more effectively address the business. All this in turn affects the prosperity of the entire society (Hauc et al. 2011).

Given that women remain an unexploited source of entrepreneurship, establishing effective mechanisms for the promotion of female entrepreneurship could be an important source of entrepreneurial ideas in Slovenia. Thus, followup studies could be enriched by the following suggestions. First, policies and programs supporting female entrepreneurship should stem from a diagnosis of the motives of prospective female small business owners, focusing on strengthening pull motives, to serve as a basis for more viable and innovative entrepreneurial activities. In addition to the personal characteristics and motivational factors necessary for devising programs and policies supporting female Slovenian entrepreneurs during the start-up phase, it would be interesting to conduct further research related to skills and competences needed not only for start-ups, but also for the development and growth of the business.

The decision to become an entrepreneur is multidimensional in scope and character. It embraces a convergence of owners' (entrepreneurs') ambitions, intentions, and competencies; internal organizational factors; region-specific resources and infrastructures; and external relationships and network configurations (Glancey 1998; Mitra/Matlay 2000; Shaw/Conwey 2000; Širec/Močnik 2010). These factors, in turn, undoubtedly impact individuals' decisions to become self-employed and offer a vast space for future research. However, future research should be systematic and continuous in order to contribute to devising policies supporting female business owners.

Based on this understanding, reasonableness and the applicability of the current research are legitimate for at least three target groups. From a societal perspective, more knowledge was presented about the factors that promote and deter entrepreneurship. From a theoretical perspective, the proposed model enriches empirical evidence on the micro level of entrepreneurship theories as well as theories of the firm. Finally, from a policy-making perspective, the current study provided a helpful tool for making choices between general and selective support for specific target groups (e.g., male versus female entrepreneurs of different types) as well as how such support should be tailored to yield a maximum return to society. 


\section{References}

Acs, Z. J. (2002): Innovation and the growth of cities. Cheltenham: Edward Elgar.

Aldrich, H. (1999): Organizations evolving. Thousand Oaks, CA: Sage Publications.

Ardichvili, A./ Cardozo, R./ Ray, S. (2003): A theory of entrepreneurial opportunity identification and development, in: Journal of Business Venturing, 18, 105-123.

Arkes, H. R./ Garske, J. P. (1982): Psychological theories of motivation. Monterey, CA: Books/Cole Publishing.

Autio, E./ Keeley, R. H./ Klofsten, M./ Ulfstedt, T. (1997): Entrepreneurial intent among university students: Testing an intent model in Scandinavia and Colorado. Paper presented at Babson/Kaufman Entrepreneurship Research Conference, April, Boston, MA, 17-20.

Barrick, M.R./ Mount, M.K. (2005): Yes, personality matters: Moving on to more important matters, in: Human Performance, 18, 359-372.

Becker, G.S. (1993): Human capital: A theoretical and practical analysis with special reference to education. Chicago: The University of Chicago Press. 390 pages.

Begley, T.M. (1995): Using founder status, age of firm, and company growth rate as the basis for distinguishing entrepreneurs from managers of smaller businesses, in: Journal of Business Venturing, 10, 249-263.

Birley, S./ Norburn, D. (1987): Owners and managers: The venture 100 versus the Fortune 500, in: Journal of Business Venturing, 2, 4, 351-363.

Bosma N./ Levie J. and Global Entrepreneurship Research Association (GERA), (2010): Global Entrepreneurship Monitor, 2009 Executive Report.

Boyd, N.G./ Vozikis, G.S. (1994): The influence of self-efficacy on the development of entrepreneurial intentions and actions, in: Entrepreneurship Theory and Practice, 18, 4, 63-77.

Brandstätter, H. (1997): Becoming an entrepreneur - A question of personality structure? in: Journal of Economic Psychology, 18, 157-177.

Burt, R.S. (1992): Structural holes. Cambridge, MA: Harvard University Press.

Caliendo, M./ Fossen, F.M./ Kritikos, A.S. (2011): Personality characteristics and the decision to become and stay self-employed. IZA Discussion Papers 5566, Institute for the Study of Labor (IZA). Retrieved September 2011, from http://ftp.iza.org/dp5566.pdf

Ciavarella, M.A./ Bucholtz, A.K./ Riordan, C.M./ Gatewood, R.D./ Stokes, G.S. (2004): The Big Five and venture success: Is there a linkage? in: Journal of Business Venturing, 19, 465-483.

Coleman, J. (1988): Social capital in the creation of human capital, in: American Journal of Sociology, 94 Supplement, S95 - S120.

Cooper, A.C. (1986): Entrepreneurship and high technology, in Sexton, D. L., Smilor, R. W. (eds.): The art and science of entrepreneurship, Cambridge, MA: Ballinger, 153-168.

Cooper, A.C./ Gimeno-Gascon, J.F./ Woo, C. (1994): Initial human and financial capital as predictors of new venture performance, in: Journal of Business Venturing, 9, 5, 371395. 
Davidsson, P. (1997): Letter pertaining to mentality differences relating to entrepreneurship. Working paper, Jönköping University, Sweden.

Dernovšek, M./ Glas, M. (2006): Women entrepreneurs in Slovenia: by fits and starts, in: Welter F., Smallbone D., Isakova B.N. (eds.): Enterprising women in transition economies, Ashgate Publishing, Ltd.

Duh, M./ Štrukelj, T. (2011): The integration and requisite holism of the enterprises' governance and management as preconditions for coping with global environmental changes, in: Acta polytech. Hung., 8, 1, 41-60.

Du Rietz, A./ Henrekson, M. (2000): Testing the female underperformance hypothesis, in: Small Business Economics, 14, 1-10.

Duchesneau, D.A./ Gartner, W. B. (1990): A profile of new venture success and failure in an emerging industry, in: Journal of Business Venturing, 5, 5, 297-312.

Dudley, N.M./ Orvis, K.A./ Lebiecki, J.E./ Cortina, J.M. (2006): A meta-analytic investigation of conscientiousness in the prediction of job performance: Examining the intercorrelations and the incremental validity of narrow traits, in: Journal of Applied Psychology, 91, 40-57.

European Commission (2003): Proceedings of the European forum on female entrepreneurship, 28 March, Brussels.

Fasci, M. A./ Valdez, J. (1998): A performance contrast of male- and female-owned small accounting practices, in: Journal of Small Business Management, 36, 3, 1-7.

Fischer, E. M./ Reuber, R. A./ Dyke, L. S. (1993): A theoretical overview and extension of research on sex, gender, and entrepreneurship, in: Journal of Business Venturing, 8, 2, 151-68.

Funder, D.C. (1994): Explaining traits, in: Psychological Inquiry, 5, 125-127.

Gal, S./ Kligman, G. (2000): The politics of gender after socialism: A comparative-historical essay. Princeton University Press.

Glancey, K. (1998): Determinants of growth and profitability in small entrepreneurial firms, in: International Journal of Entrepreneurial Behavior \& Research, 4, 1, 18-27.

Granovetter, M. (1992): Problems of explanation in economic sociology, in: N. Nohria/Eccles R. (eds.): Networks and organizations, Boston, Massachusetts: Harvard Business School Press, 25-56.

Gray, C. (2000): Formality, intentionality, and planning: Features of successful entrepreneurial SMEs in the future? Paper presented at the ICSB World Conference 2000, Brisbane, Australia, June.

Green, E./ Cohen, L. (1995): Woman's business: are woman entrepreneurs breaking new ground or simply balancing the demands of woman's work in a new way? in: Journal of Gender Studies, 4, 3, 297-315.

Greene, P. G./ Hart, M. M./ Gatewood, E. J./ Brush, C. G./ Carter, N. M. (2003): Women entrepreneurs: moving front and center: An overview of research and theory, Coleman White Paper Series, 3, 1-47. Retrieved September 2008, from http://www.usasbe.org

Hauc, A./ Vrečko, I./ Barilović, Z. (2011): A holistic project-knowledge society as a condition for solving global strategic crisis, in: Društvena istraživanja, 20, 4 (in press). 
Honig, B. (1998): What determines success? Examining the human, financial and social capital of Jamaican microentrepreneurs, in: Journal of Business Venturing, 13, 5, 371394. Retrieved September 2008, from http://www.onlinwwomenpolitics.org/beijing12/ Women_2000.pdf

Johnsen, G. J./ McMahon, R. G. P. (2005): Owner-manager gender, financial performance and business growth amongst smes from australia's business longitudinal survey, in: International Small Business Journal, 23, 2, 115-142.

Johnson, L. jr. (1994): Attributional style as a distinguishing factor of entrepreneurial achievement motivation. California School for Professional Psychology, Los Angeles, CA, (dissertation).

Jones, O./ Tilley, F. (2003): Competitive advantage in SMEs. Organising for innovation and change. Wiley \& Sons, 408 pages.

Kets de Vries, M.F.R. (1977): The entrepreneurial personality at the crossroads, in: Journal of Management Studies, 14, 34-57.

Kihlstrom, R./ Laffont, J. (1979): A general equilibrium theory of firm formation based on risk aversion, in: Journal of Political Economy, 87, 719-748.

Klapper, L.F./ Parker, S.C. (2010): Gender and the business environment for new firm creation. (O. U. Press, Ed.) The World Bank Research Observer, 1-21.

Korman, A.K. (1970): Toward a hypothesis of work behavior, in: Journal of Applied Psychology, 54, 1, 31-41.

Liao, J./ Welsch, H. (2003): Social capital and entrepreneurial growth aspiration: A comparison of technology- and non-technology-based nascent entrepreneurs, in: The Journal of High Technology Management Research, 14, 149-170.

Lin, N. (1999): Social networks and status attainment, in: Annual Review of Sociology, 25, 467-487.

Lumpkin, G.T./ Dess, G.G. (1996): Clarifying the entrepreneurial orientation construct and linking it to performance, in: Academy of Management Review, 21, 1, 135-172.

Maki, K./ Pukkinen, T. (2000): Barriers to growth and employment in Finnish small enterprises. Paper presented at the ICSB World Conference 2000, Brisbane, Australia, June.

Manev, I.M./ Gyoshev, B.S./ Manolova, T.S. (2005): The role of human and social capital and entrepreneurial orientation for small business performance in a transitional economy, in: International Journal of Entrepreneurship and Innovation Management, 5, 3/4, 298-318.

Manolova, T. S./ Brush, C. G./ Edelman, L. F./ Greene, P. G. (2002): Internationalization of small firms: International factors revisited, in: International Small Business Journal, 20, 1, 9-13.

Maula, M./ Autio, E./Murray, G. (2001): Prerequisites for the creation of social capital and subsequent knowledge acquisition in corporate venture capital, in: W.D. Bygrave, E. Autio, C.G. Brush, P. Davidsson, P.G. Greene, P.D. Reynolds and H.J. Sapienza (eds.) Frontiers of Entrepreneurship Research. Proceedings of the Babson Kauffman Conference on Entrepreneurship Research (Wellesley, MA: Babson College), 536548 . 
McClelland, D.C. (1961): The achieving society. NY: Van Nostrand.

Miller, D./ Friesen, P.H. (1982): Innovation in conservative and entrepreneurial firms: Two models of strategic momentum, in: Strategic Management Journal, 3, 1-25.

Miner, J. B. (1993): Role motivation theories. New York: Routledge.

Miner, J.B. (1997): A psychological typology of successful entrepreneurs. Westport, CT: Quorum Books.

Minniti, M./Nardone, C. (2007): Being in someone else's shoes: The role of gender in nascent entrepreneurship, in: Small Business Economics, 28, 2/3, 223-238.

Mitra, J./ Matlay, H. (2000): Toward the new millennium: The growth potential of innovative SMEs. Paper presented at ICSB World Conference, Brisbane, Australia, June.

Mondragon-Velez, C. (2009): The probability of transition to entrepreneurship revisited: Wealth, education and age, in: Annals of Finance, 5, 3, 421-441.

Moore, D./ Buttner, H. (1997): Women entrepreneurs moving beyond the glass ceiling. Thousand Oaks, CA: Sage.

Müller, G.F. (2001). Biographical factors of occupational independence, in: Psychological Reports, 89, 309-314.

Müller, G.F./ Gappisch, C. (2005): Personality types of entrepreneurs, in: Psychological Report, 96, 737-746.

Nahapiet J./Ghoshal, S. (1998): Social capital, intellectual capital, and the organizational advantage, in: Academy of Management Review, 23, 242-266.

OECD (2004): Women's Entrepreneurship: Issues and Policies. Paris: OECD.

Ogloblin, G.C. (1999): The gender earnings differential in the Russian transition economy, in: Industrial and Labor Relations Review, 52, 4, 602-627.

Polanyi, M. (1967): The tacit dimension (2nd ed). New York: Anchor Books.

Rauch, A./ Frese, M. (2007): Let's put the person back into entrepreneurship research: A meta-analysis on the relationship between business owners' personality traits, business creation, and success, in: European Journal of Work and Organizational Psychology, $16,353-385$.

Rebernik, M./ Tominc P./ Crnogaj K. (2011): Podjetniška aktivnost, aspiracije in odnos do podjetništva (Entrepreneurial activity, aspirations and entrepreneurial attitutes), GEM Slovenija 2010, (Slovenski podjetniški observatorij). Maribor: Ekonomsko-poslovna fakulteta.

Rebernik, M./ Tominc P./ Pušnik K. (2010): Podjetništvo v letu krize (Entrepreneurship in the year of crisis), GEM Slovenija 2009, (Slovenski podjetniški observatorij). Maribor: Ekonomsko-poslovna fakulteta.

Rebernik, M./ Širec K. (2007): Fostering innovation by unlearning tacit knowledge, in: Kybernetes, 36, 3/4, 406-419.

Reynierse, J.H. (1997): An MBTI model of entrepreneurism and bureaucracy: The psychological types of business entrepreneur compared to business managers and executives, in: Journal of Psychological Type, 40, 3-19. 
Rosa, P./ Carter, S./ Hamilton, D. (1996): Gender as a determinant of small business performance: Insights from a British study, in: Small Business Economics, 8, 463-478.

Rotter, J. B. (1966): Generalized experiences for internal versus external control of reinforcement, in: Psychological Monographs, 609a.

Ruminska-Zimny, E. (2003): Women's entrepreneurship and labour market trends in transition countries, in: Women's entrepreneurship in Eastern Europe and CIS Countries, 1-16.

Ruzzier, M. (2004): The internationalization of small and medium enterprises: The influence of the entrepreneur's human and social capital on the degree of internationalization. Univerza v Ljubljani, Ekonomska fakulteta, (dissertation).

Sexton, D. L./ Bowman, N. (1986): Validation of a personality index: Comparative psychological characteristics analysis of female entrepreneurs, managers, entrepreneurship students and business students, in: Ronstadt, R., Hornaday, J., Peterson, R., Vesper, K. (eds.): Frontiers of Entrepreneurship Research, Babson College, Boston, MA, 40-51.

Shanthakumar, D.K. (1992): Attitudinal characteristics of male and female entrepreneurs in India and a comparison with American entrepreneurs. Brigham Youth University, UT, (dissertation).

Shaver, K.G. (1995): The entrepreneurial personality myth, in: Business and Economic Review, 41, 3, 20-23.

Shaw, E./ Conway, S. (2000): Networking and the small firm, in: Carter S. /Jones-Evans D. (eds.): Enterprise and Small Business. Harlow, UK: Financial Times/Prentice Hall, 367-383.

Širec, K. (2007): The impact of entrepreneurial opportunities, firm abilities and entrepreneurs' personal characteristics on SMEs. University of Mariboru, Faculty of Econmics and Business, (dissertation), Februar.

Širec, K./ Močnik, D. (2010): How entrepreneurs' personal characteristics affect SMEs' growth $=$ Vpliv podjetnikovih osebnih lastnosti na rast MSP, in: Naše gospodarstvo, $56,1 / 2,3-12$.

Širec, K./Rebernik, M. (eds.) (2010): Vrzeli slovenskega podjetniškega okolja: Slovenski podjetniški observatorij 2009/10, (Slovenian Entrepreneurship Observatory). Maribor: Ekonomsko-poslovna fakulteta.

Smallbone, D./ Welter, F. (2001): The distinctiveness of entrepreneurship in transition countries, in: Small Business Economics, 16, 4, 249-262.

Solymossy, E. (1998): Entrepreneurial dimensions: The relationship of individual, venture, and environmental factors to success. Department of Marketing and Policy, Weatherhead School of Management, Case Western Reserve University, (dissertation).

Statistical Office of the Republic of Slovenia, 2009, Statistical yearbook of the Republic of Slovenia, 2009. Ljubljana: Statistical office of the Republic of Slovenia.

Stevenson, H.H. (1983): A Perspective on entrepreneurship. Harvard Business School Note, No. 9-384-131.

Stoyanovska, A. (2001): Jobs, gender and small enterprises in Bulgaria. Geneva: ILO. 
Tominc, P. (2002): Some aspects of the gender wage gap in Slovenia, in: Društvena istraživanja, 11, 6, 879-896.

Tominc, P./ Rebernik, M. (2006): Female entrepreneurial growth aspirations in Slovenia: an unexploited resource, in: Brush, C.G., Carter, N.M., Gatewood, E., Greene, P.G., Hart, M.M. (eds.): Growth-oriented women entrepreneurs and their businesses: A global research perspective, (New horizons in entrepreneurship). Cheltenham (UK); Northampton (Mass.): E. Elgar, cop., 330-347.

Van der Sluis, J./ van Praag, M., et al. (2008): Education and entrepreneurship selection and performance: A review of the empirical literature, in: Journal of Economic Surveys, $22,5,795-841$.

van der Zwan, P./ Verheul, I./ Thurik, A.R. (2011): The entrepreneurial ladder, gender, and regional development, in: Small Business Economics, published online 03 April 2011.

Verheul, I./ Thurik, R./ Grilo, I./ van der Zwan, P. (2011): Explaining preferences and actual involvement in self-employment: Gender and the entrepreneurial personality, in: Journal of Economic Psychology, published online, doi:10.1016/j.joep.2011.02.009.

Zhao, H./ Seibert, S. (2006): The Big Five personality dimensions and entrepreneurial status: A meta- analytic review, in: Journal of Applied Psychology, 91, 2, 258-271.

Zhao, H./ Seibert, S.E./ Hills, G.E. (2005): The mediating role of self-efficacy in the development of entrepreneurial intentions, in: Journal of Applied Psychology, 90, 1265-1272.

Zhao, H./ Seibert, S.E./ Lumpkin, G.T. (2010): The relationship of personality to entrepreneurial intentions and performance: A meta-analytic review, in: Journal of Management, 36, 2, 381-404. 